\title{
France: Gaullist legacy casts a long shadow
}

Paris. France emerged from the Second World War with its infrastructure and laboratories ravaged by the German occupation. Fifty years later, France is a leader in many areas of basic science, and a high-technology showpiece. A nuclear weapons state, France has also dragged Europe into space, and provided the impetus for the development of Europe's Airbus airliners.

The foundations of the current system were laid immediately after the war under General Charles de Gaulle, and during de Gaulle's second term of office (1958-69). Science then stagnated under the presidencies of Georges Pompidou and Valéry Giscard d'Estaing (1969-81), and was rejuvenated under that of François Mitterrand (1981-95). Similarly, many of the constraints of the system originate in the strategic choices made during France's postwar reconstruction, and later during its efforts to re-cstablish itself as an international power.

The state began to play a significant role in French research in 1938, when it became the first country to appoint a science minister, Irène Joliot-Curie. The Parti populaire government proceeded, one year later, to create the Centre National de la Recherche Scientifique (CNRS), today Europe's largest fundamental research organization.

Both moves were aimed at closing the gap between industry and research, most of which was then carried out in the state-run universities. These refused to carry out applied research, while French industry lagged behind its competitors, who had developed large research-based companies in, for example, chemicals and electricity.

CNRS itself narrowly avoided being abolished in 1940 by the collaborationist Vichy regime. It emerged strengthened after the liberation, as many of its leaders were communists or had taken part in the resistance movement. But it was forced to modify its original goals during the late 1940s, as France began to seek alternative routes to harness research to the reconstruction of the country.

CNRS's original mandate to carry out targeted research was compromised when much of this was farmed out to a series of newly created agencies, such as the Commissariat à l'Energie Atomique (CEA) and the agricultural research organization INRA'. The existence of these new research agencies also prevented CNRS from fulfilling its mandate to coordinate a national research

1. Jean-Francois Picard, La république des savants, La recherche francaise et le CNRS. Flammarion, 1990

. Marie-José Lovérini, Le Commissariat à l'Ėnergie Atomique, Gallimard, 1995

3. Michel Morange, Histoire de la biologie moléculaire, La Decouverte, 1994

4. Jean-Jacques Salomon, La capacité d'innovation, in Entre l'état et le marché, L'économie francaise des années 1880 à nos jours. eds M. Lévy-Leboyer and J.C. Casanova, Gallimard, 1991.

policy. This had to wait until 1958, when de Gaulle returned to power.

CNRS nonetheless made a major contribution to the renovation of French science after the war. It provided a channel for money from the Rockefeller Foundation, for example, which provided much needed

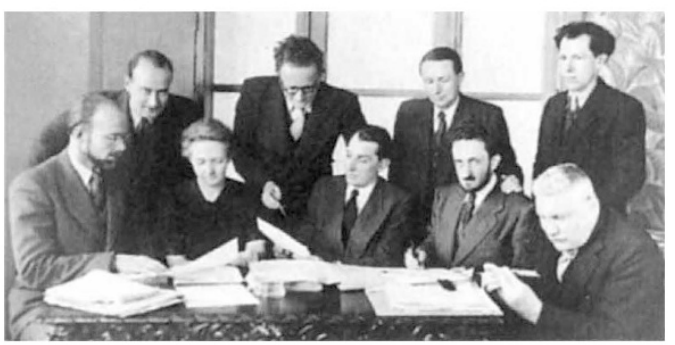

The beginnings of the CEA: from left to right (seated) Pierre Auger, Irène et Frédéric Joliot, Francis Perrin, Lew Kowarski; standing, Betrand Goldschmidt, Pierre Bicquard, León Denievelle and Jean Langevin.

equipment and supplies. More broadly, the creation of CNRS, together with the appointment of a research minister, initiated the institutionalization of state support for science. This trend gathered pace, after the liberation, when the state set up research organizations in a deliberate bid to catch up with the United States.

Indeed, the US model of carrying out research directed towards specific goals, which had proved so effective during the war, fitted well with the neo-Colbertist approach of de Gaulle, who chose detailed planning as the means to address the most pressing problems of reconstruction, such as developing energy, materials and transport. Where a strong base existed, as in nuclear power, electricity, and railways, France achieved rapid progress.

In fact, next to the reinstatement of the CNRS, the single most important event in post-war French science was perhaps the creation of CEA, which brought enormous resources to bear on the development of both nuclear energy and nuclcar weapons, and provided broad stimulus to fundamental research in physics ${ }^{2}$. (In contrast, French biology had to wait for its reconstruction until the late $1950 \mathrm{~s}$, when the government made molecular biology a priority, and spectacular advances were also made at the Institut Pasteur by André Lwoff, François Jacob and Jacques Monod ${ }^{3}$.)

The initial momentum created immediately after the war was lost, however, following the resignation of de Gaulle in 1946. Renewal began again in earnest only in the 1950 s, first under the socialist government of Pierre Mendès-France - which organized a conference on research in 1956 at Caen, aimed at developing a national strategy for research - and in particular after 1958, when de Gaulle returned to power and established the Fifth Republic.
It was in that year, for example, that the government created an interministerial committee on research, as well as another widely acclaimed body, the Délégation générale à la recherche scientifique et technique. The role of the latter was to plan national research programmes in strategic areas such as molecular biology and space.

During de Gaulle's reign from 1958 to 1969 , science spending increased from 2.45 to 6.2 per cent of the state budget, while the number of researchers jumped from 9,000 to 31,000 . A wave of new agencies, including the French space agency CNES, were also created to reinforce the grands programmes.

The achievements resulting from de Gaulle's policies are undeniable. Electricité de France (EDF), for cxample, has established an efficient park of nuclear reactors, and there is now an impressive high-speed rail network. France has succeeded - where the United Kingdom and other countries have failed - in creating successful nationalized industries largely because these are run by élites, specially trained at the country's grandes écoles.

But state intervention - and these élites - is now coming under fire as ill-suited to both the increasing pace of technological change, and the need to adopt an aggressive strategy in a highly competitive global economy.

Indeed, many argue that the state's emphasis on the grands programmes has led to a neglect of innovation in the private sector, particularly in small companies ${ }^{4}$. Economic success also increasingly depends on sectors such as lasers, robotics, computing and biotechnology which are unsuited to state planning, and better served by fastmoving and flexible private companies.

Conversely, confusion about the role of CNRS may also have limited its effectiveness. From its beginning, the agency has been responsible for funding university research, and continues to fulfil that role today. But some observers argue that this dual role has made CNRS 'schizophrenic' by confusing its goals - namely support for its own research and that of the university system - and even inhibiting the development of a strong university system.

The only French universities carrying out international-level research are those that have large teams of CNRS researchers. This reflects the fact that, over the past 50 years, CNRS support has been a major factor allowing French universities to modernize themselves. But many now argue that the universities will be able to develop a strong research capacity only when this dependency is broken and they have regained full control of their research budgets. Declan Butler 